\title{
IAMJ
}

INTERNATIONAL

AYURVEDIC

MEDICAL JOURNAL

\section{A MUTLI-DIMENSIONAL APPROACH TO PAPILLEDEMA BY ADOPTING SHOTHA CHIKITSA - A SINGLE CASE STUDY}

\author{
$\underline{\text { Sucha Lakshmi } \mathbf{R}^{1}}$, Nirmal Krishnan $\mathbf{R}^{2}$, $\underline{\text { Rathi }}^{3}$ \\ ${ }^{1} \mathrm{P}$ G Scholar, ${ }^{2} \mathrm{P}$ G Scholar, ${ }^{3}$ Associate Professor, \\ Dept of PG Studies in Shalakya Tantra, Govt Ayurveda Medical College Bengaluru, Karnataka, India
}

Corresponding Author: drnirmalkr94@gmail.com

\section{https://doi.org/10.46607/iamj14p4062020}

(Published online: September 2020)

Open Access

(C) International Ayurvedic Medical Journal, India 2020

Article Received: 07/09/2020 - Peer Reviewed: 09/09/2020 - Accepted for Publication: 12/09/2020

\section{Check for updates}

\section{ABSTRACT}

Introduction: Shotha ${ }^{l}$ is the generic name told by Ayurveda Aacharyas correlating to inflammation or oedema affecting in any part of the body. Detailed description of anti-inflammatory measures is available in Ayurveda classics to handle such ailments. Ekanga Shopha is explained in Ayurveda Bruhathrayees, as an inflammation in any particular part of the body or organ, Papilledema is also such local inflammation which we can take into consideration as Ekanga Sopha. Papilledema is defined as passive oedema of optic disc in the eyes, secondary to raised intracranial pressure. Its incidence is getting increased day by day due to defective lifestyle and other aetiologies. Objectives: The objectives of this study are to evaluate the efficacy of Shodha Chikitsa in the management of papilledema. Methodology: A 64-year-old female patient having symptoms of papiledema selected for the study. By considering the papiledema as Drushti Anthara Sopha or Drishti Nadishotha and adopted the Shobha Chikitsa. The patient underwent with Nasya, Seka, and Thakradhara for 14 days. Punarnavashtaka kashaya, Navayasa choorna, Chandraprabha vati, Sapthamrutha loha given as internal medicine for 2 months. Results: The papilledema got regressed after 2 months of treatments and the patient got continuously monitored for one year and no reoccurrence found. Conclusion: Papilledema is a serious eye ailment which is not having permanent solution in other medical science but can be easily managed with Ayurvedic medicaments. It is the Yukthi of the 
Vaidya to adopt the treatments like Sothahara Chikitsa etc. to make the patients get recover from ailments like optic disc oedema or Papilledema.

Keywords: Papilledema, Shotha, Nasya Seka Takradhara,Punarnavashtaka kashaya, Navayasa choorna, Sapthamrutha loha

\section{INTRODUCTION}

The term Shotha told in Ayurveda classics have synonyms like Shopha, Swayathu, Uthswedha, Samhana but it literally means a swelling because of inflammatory process in any part of the body or may be general oedema. Shotha affecting body may occur as either Swatantra Vyadhi (primary) or Paratantra ${ }^{7}$ (secondary) Vyadhi. There are various aetiologies are explaining in the occurrence of Sopha, some might be occurring due to Dosha vitiation or some might be due to Abhighata or trauma. It may also occur as a symptom of other diseases. Keeping this concept of Shotha in view, papilledema can be considered as Drishti Anthara Shodha/ Drishti Nadi Shodha [as optic nerve is associated] which may be primary or secondary. However, exactly the term papilledema has been referred for the passive disc swelling associated with increased intracranial pressure, which is almost always bilateral. Sometimes, it may be asymmetrical in both eyes. Symptoms can include visual disturbances, headache and nausea. If not treated in time, this condition can lead to optic atrophy and total loss of vision. In the early stages, Papilledema may be asymptomatic or present with mild symptoms like headache. It can progress to enlargement of the blind spot, blurring of vision, visual obscuration (inability to see a particular part of the visual field for a period of time) ultimately, total loss of vision can occur. The main pathology behind this ailment is raised intracranial pressure happens due to any trauma and transient loss of vision occurs gradually. By considering trauma as Shiroabhithapa ${ }^{2}$, Shotha Chikitsa is taken into consideration. After getting Abhithapa, Dosha vitiation happens which is Moolakarana of Shodha. In this case study, a female patient of papilledema presented with Kapha-Pitta predominant Shodha symptoms in eye was selected. She was having symptoms like blurring of vision, headache, Mild nausea, heaviness of both eyes, mild pain in left eye. Headache was getting severe in morning hours. Patient was diagnosed as bilateral Papilledema and signs elicited more in the right eye than the left. In ayurvedic view, this case had been diagnosed as Drishti Nadi Shotha or Drishti Anthara Sodha.

\section{Case Report:}

A female patient aged 64 years visited OPD in Department of Shalakya Tantra, Govt Ayurveda Medical college, Bengaluru. She was presenting with complaints of blurring of vision, double vision occasionally, head ache felt severe in morning hours, Mild nausea, heaviness in both eyes, mild pain in left eye, For these complaints, patient had undergone treatment by an Opthalmologist and was provisionally diagnosed as Bilateral Papilledema with benign intracranial hypertension(comparatively more in the left than right eye). Patient was on tablet Diamox $250 \mathrm{mg}$ (Acetazolamide twice a day for Intracranial hypertension), but was complained of dizziness, ringing sounds in ears, generalized weakness after taking this tablet. Even after taking medication for 4 months, patient had persistent heaviness in head and headache. Hence, patient wanted to discontinue it and thus, came for Ayurvedic treatment. In the past history, she is a known case of hypertension since 11 years on antihypertensive (tablet Ramipril $50 \mathrm{mg}$ once a day), and blood pressure was under control. She is suffering from Diabetes mellitus since 7 years and on Oral Antihyperglycemic agent (tablet Glimipiride $500 \mathrm{mg}$ ), blood sugar level was - fasting $134 \mathrm{mg} \%$ and postprandial $162 \mathrm{mg} \%$.

\section{Ocular Examination:}

$>$ Visual acuity - Distance vision acuity (DV) - 6/9 Rt 6/24 Lt,

- Near Vision (NV) - N/8 BE 
$>$ Intraocular pressure (IOP) - $18 \mathrm{~mm} \mathrm{Hg} \mathrm{Rt} / 22$. $\mathrm{mmHg}$ Lt

$>$ Third, fourth, and sixth cranial nerve in BEs were normal. Normal ocular movements, No evidence of Ptosis etc

$>$ Corneal reflex is normal.

$>$ Slit lamp examination - Normal AC, Non Chemosed Conjunctiva, no keratitis found, no Iritis found, anterior uveal tract appears normal

$>$ Pupil- - no afferent pupillary defect., RRR-BEs. $3 \mathrm{~mm}$ in diameter

\section{$>$ Fundoscopy disc}

- Right eye - mild papilledema

- Left eye - moderate papilledema.

Retinal haemorrhage - elicited

Retinal exudates - nil

Hypertensive retinopathy changes- mildly appreciated with flame shaped haemorrhages in inferio-nasal part of left eye.

Considering above criteria, patient had been diagnosed as Benign raised intracranial hypertension leading to Papilledema, which is painless swelling of the optic disc with hyperemia of the disc with engorged retinal vessels. From ayurvedic point of view, it was diagnosed as Kapha-Pittaja Shotha happened to the Netra Nadi or optic disc and treated on the line of Shotha Chikitsa.

\section{Line of Management:}

The following treatment was administered: (Table 1)

- Dipana Pachana - Chithrakadi Vati - 2 tablets twice daily before meals for 3 days

* Koshta Shuddhi - Trivruth lehya 30 gm with lukewarm water at empty stomach morning on $4^{\text {th }}$ day

* Dosha Pratyanika Chikitsa: Kriyakalpa \& Abhyanthara prayoga

Kriyakalpa - Nasya with Anutailam 7 days

NethraSeka with Guduchi, lodra, Punarnava, Daruharidra for 7 days

Thakra dhara [Takram mixed with Vaasakadhi Kashayam + Musta Amalaki kashayam used for Shirodhara] for 7 days.

Abhyanthara Prayoga - Punarnavashtaka Kashaya each $10 \mathrm{ml}$ twice daily orally with $20 \mathrm{ml}$ lukewarm water on empty stomach. Navayasa Choorna 5gm twice daily with Takra. Chandraprabha Vati one tablet twice daily before food. Sapthamrutha Loha two tablet bedtime with unequal quantity of honey and ghee.

Total duration of treatment was 2 months.

\section{Observation and Results}

The patient started feeling better in blurring of vision, double vision etc. after administeringg the treatment Nasya and Nethra seka. Slight heaviness in the left eye was still persisted. But during the treatment of Takradhara patient reported gradual improvement in the heaviness of the eyes and head. There was a massive reduction of episodes of headache also. After 1 month of treatment, a decrease in Papilledema was observed. Patient was getting monitored daily for the difference of intra ocular pressure. And it was found that the IOP was getting normal gradually during the treatment period. Blood sugar level was normal (within biological limit). On follow-up of more than 1 year, patient was asymptomatic on examination, Papilledema of both eyes had been completely regressed.

\section{DISCUSSION}

While explaining the Pramana to attain and implementing the knowledge, Acharya Charaka explained Yukti Pramana- it is the best intellectual ability of a physician and said to be permitted to modulate the disease management as per the wish of physician itself. As mentioned in Vimana Sthana in the context of Anukta Vyadhi, for the management of diseases which are not named in the text, the physician should use his knowledge, intelligence and try to comprehend the vitiated Dosha and treat it accordingly. Though there is no definite treatment protocol in the management of Benign raised intracranial pressure presenting with Papilledema, with the clinical experiences, an attempt was made to treat this clinical entity on lines of Shotha Chikitsa. Thus, the treatment aimed at reducing the Shotha by administering Shothahara preparations such as Punarnavashtaka Kwatha. etc along with other internal medication, the local procedure Takradhara (Ruksha, Sheeta quality) seka with Sothahara drugs and Nasya with Anu Tailam to pacify 
Kapha and Pitta Dosha were planned. At the same time by giving due consideration to control diabetes, Chandraprabha was administered. As Sapthamrutha loha yields best Chakshusha property, it was also administered. The patient responded well both subjectively and objectively to the treatment.

Nasyam with Anutailam - Nasyam explained as prime Shodhana procedure in Urdhwajatru Vikaras because this treatment procedure having direct impact on Shringadaka etc Marma. Nasa is the only gateway towards Shiras and Nasyam is the best treatment plan to be adopted. Anutaila clears the Shirogata Srotas and facilitates the body for further treatment modalities.

Sekam - Netra Sekam otherwise called Netradhara and drugs like Punarnava, Lodra Guduchi etc which are marked for their anti-inflammatory activities. These drugs will help to clears the media and improve transparency of humors inside and helps in clarity of vision.

Special Takradhara - Takradhara is Rooksha KaphaPitha Hara which will do its good impact on oedematous area. Usually, Takra is added with Musta and Amalaki Kashayam and Takradhara dravya is preparing by churning the contents. But here an alternate method of Sthanika Sotha Chikista was done with external application of Vaasakadi Kashayam. Instead of using orally, freshly prepared Vaasakadi Kashayam mixed with Takram used for Takradhara. The Vaasakaadi Kwatha contains ingredients like Vasa, Nimba, Musta, Haritaki, Bibhitaki \& Amalaki which were taken in equal quantity and powdered separately. The Kwatha was prepared according to Acharya Sharangadhara's view of method of preparation of Madhyama Kashaya Kalpana Vidhi. Then mixed with Takra along with Amalaki and Musta Kashaya, churned well and used for Takradhara.

Navayasa Choornam: Shunti (Zingiber officinalis) Pippali (Piper longum) Maricha (Piper nigrum) Haritaki (Terminalia chebula) Vibitaki (Terminalia bellirica), Amalaki (Emblica officinalis), Mustha (Cyperus rotundus) Vidanga (Embelia ribes) Chitraka (Plumbago zeylanicum) Ayoraja/loha bhasma (Iron oxide) The Formulation is explained in Pandu roga where Sopha is mentioned as a complication and are proven to be best for their anti-inflammatory activity.

Punarnavashtaka Kwatha: Punarnava (Boerrhavia diffusa), Nimba (Azadirachta indica), Patola (Trichosanthes dioica), Shunthi (Zingiber officinalis), Kutki (Picrrorhiza kurroa), Guduchi (Tinospora cofdifolia), Devdaru (Cedrus deodara), Haritaki (Terminalia chebula) are having antioxidant, diuretic, antiinflammatory as well as antimicrobial properties.

Chandraprabha - It is very commonly used drug for controlling blood sugar, having Mutrala property also. The Drugs like Shilajathu, Guggulu (Commiphora mukul) Ativisha (Aconitum heterophyllum) etc. in this formulation are having miraculous action in reducing fluid retention and thus causes marked reduction in odema inside the disc.

Sapthamrutha loha Amalaki (Emblica officinalis), Haritaki (Terminala Chebula) Vibhitaki (Terminala bellirica). Yashti Madhu (Glycyrrhiza glabra). This formulation is metabolism balancer and eye nutrinetonic also.

\section{CONCLUSION}

New ocular disorders like Papilledema is not described in ancient texts. It is difficult to find out a perfect correlation from Ayurveda treatises for such eye diseases. But through analyzing the vitiated Doshas based on the signs and symptoms, the entity papilledema can be considered as Kapha-Pitta predominant Drishti Nadi Shotha or Drishti Anthara Sotha and managed by following the treatment prescribed for Shotha. The Pappilledema is the disc oedema and here taken into consideration as Ekanga Sopha, there by Shopha Chikitsa is administered which yielded better results within limited period of time.

\section{REFERENCES}

1. Acharya YT, editor. Charaka Samhita of Agnivesha, Sutrasthana. Reprint Edition. Ch. 18, Ver. 5. Varanasi: Chaukhambha Orientalia; 2011. p. 106.

2. Khurana AK. Neuropthalmology. In: Comprehensive Ophthalmology. 4th ed. New Delhi: New Age International (P) Limited Publication; 2007. p. 319-22. 
3. Krishna KV, editor. Sahasrayoga, Kashaya Kalpana. 25th ed. Alleppy: Vidyarmbha Publication; 2004. p. 34.

4. Krishna KV, editor. Sahasrayoga, Dhara Kalpa. 25th ed. Alleppy: Vidyarmbha Publication; 2004. p. 475

5. Rathore RS, Prakash A, Singh PP. Premna Integrefolia Linn., A preliminary study of anti-inflammatory activity. Rheumatism 1977; 12:130-4.
6. Katiyar C K, Brindavanam NB, Tiwari P, Narayana DB. Immunomodulator products from Ayurveda: Current status and future perspective. In: Upadhyaya $\mathrm{SN}$, editor. Immunomodulation. New Delhi: Narosa Publishing House; 1997. p. 163-87.

Table 1: Treatment Plan

\begin{tabular}{|l|l|l|l|}
\hline SI no & Treatment plan & Medicine & Duration \\
\hline 1. & Dipana Pachana & Chithrakadi vati & 3 days \\
\hline 2 & Koshtasudhi / Virechana & Trivruth lehyam & $4^{\text {th }}$ day \\
\hline 3 & Nasyam & Anutailam & $6-12$ th day \\
\hline 4 & Netra Sekam & Guduchi, Lodra, Punarnava, Daruharidra & 12- 19th day \\
\hline 5 & Special Takradhara & Mixed with Vaasakadi Kashayam + Musta Amlaki kashayam & 12- 19th day \\
\hline 6 & Internal medications & $\begin{array}{l}\text { Punarnavashtaka Kashaya Navayasa choorna Chandra prabha vati } \\
\text { Sapthamrutha loha }\end{array}$ & 2 months \\
\hline
\end{tabular}

\section{Source of Support: Nil \\ Conflict of Interest: None Declared}

How to cite this URL: Sucha Lakshmi R: A Mutli-Dimensional Approach to Papilledema by Adopting Shotha Chikitsa - A Single Case Study. International Ayurvedic Medical Journal \{online\} 2020 \{cited September, 2020\} Available from: http://www.iamj.in/posts/images/upload/2531 2535.pdf 